\title{
22
}

\section{Global governance of labour migration: From 'management' of migration to an integrated rights-based approach}

\author{
Nicola Piper
}

\section{Introduction}

In recent years, international migration has reached a firm place on the global policy agenda as evidenced by a flurry of activities and actors involved, amounting to what some commentators have come to call the 'global governance of migration' (Grugel and Piper 2007; Betts 2011; Koser 2010).

The idea of global governance in its various conceptualisations has emerged to capture the cooperation or coordination of different actors (governmental, non-governmental and international organisations) within a network made up of formal and informal rules to reform institutions of 'the global' (Rittberger 2001; Kennedy et al. 2002). As a concept that took off gradually after the end of the Cold War, global governance has been used not solely for the description and analysis of complex structures within a globalising world that is no longer subject to classification into 'first, second and third worlds'. This concept is also part of a wider attempt to change this 'new' world into something different or better in a normative sense (Habermann 2011). 
Falk (1995) distinguishes between 'inhumane' and 'humane' governance, with the former characterised by unequal distribution of wealth and extensive violation of human rights; the latter, in contrast, emphasises people-centred criteria of progress-measures such as declines in poverty and adherence to human rights. 'Humane' governance has been reconceptualised as rights-based governance, based on an approach to rights beyond the sphere of international law, thus reflecting the increasing purchase of rights discourses and rights activism emanating from civil society (Grugel and Piper 2007).

Rights-based governance is essentially and necessarily driven 'from below'-that is, a project that involves or derives from collective activism by social movements and transnational advocacy networks. This is even more so the case for migrant workers who find themselves marginalised as noncitizens or 'absentee citizens', and thus in a particularly precarious situation in social, economic, legal and political terms. In this sense, rights-based governance mirrors other decentred conceptualisations of governance, such as networked or nodal governance (see Charlesworth, Chapter 21; and Holley and Shearing, Chapter 10, this volume). What distinguishes rights-based governance, however, is the struggle to advance and promote social justice for noncitizens who not only have had their rights seriously restricted but are also facing enormous hurdles in politically agitating for their rights. In other words, migrant workers - as both noncitizens and workers in primarily low-wage sectors or types of work rejected by locals-are increasingly excluded from the process of forging organisations with which to network and through which to channel their concerns and demands. This is why insights from political sociology - a component missing from existing work on global migration governance (but see Grugel and Piper 2007)—are vital.

Recognition that, as a policy field, international migration for employment requires not only bilateral but also effective global regulation has come very late when compared with other issue areas that have been subject to global governance for some time, such as trade, health and finance (Jönsson and Tallberg 2010; Betts 2011; Koser 2010). Yet, international migration is among the key features of economic globalisation today 
(Standing 2008), and, as a truly global phenomenon, migration implicates most, if not all, countries in the world in one form or another, as major migrant senders and/or receivers. ${ }^{1}$

The discourse and concomitant policy prescriptions that have resulted so far from this new international cooperation on migration have largely centred on what some have referred to as 'the paradigm of managed temporary labor migration' (Chi 2008: 500). The 'management of migration' discourse is linked to the renewed interest in migration's contribution to development (the 'migration-development nexus'), placing great emphasis on the design of formal policies by which origin and destination states try to assert control over migratory flows and access to employment - that is, over income and profit generation as well as the securing of livelihoods through migration. In essence, what have emerged are attempts at 'managing migration' in the sense of peoples' cross-border movements alongside 'managing poverty' through access to overseas employment. Temporary contract migration schemes are attractive as they allow destination countries to adjust their workforce to the cyclical nature of economies without further commitments (turning migrants into what political economists would refer to as 'disposable labour'), while ensuring a steady flow of remittances on which many countries of origin heavily depend. As a result of this scenario, however, migrants' labour and human rights are more and more curtailed.

Being in practice embedded in an increasingly restrictive policy environment based on selective if not discriminatory criteria, current policy practices heavily circumscribe the human rights of migrants. Despite the existing set of comprehensive international human rights instruments for the protection of migrant workers, as low-skilled/ low-wage temporary contract workers, many migrants in fact find themselves in highly vulnerable and exploitative situations. As it is argued here, migration governance, therefore, continues to fail in several key areas, as reflected in decent work deficits with regard to employment opportunities, labour rights and social protection. This is so because 'management of migration' is not accompanied by the management of working conditions and labour relations. In addition-and related to this decent work deficit-many migrants are unable to function as 'agents of development' through the acquisition of skills and savings

1 Some countries are classified as 'transit countries', but often migrants whose original intention was to move on remain. In other words, transit countries often become destination countries. 
that would turn them into 'entrepreneurs' on return to their home communities (Spitzer and Piper 2014). It is the nascent global migrant rights movement, supported by a number of global trade unions, that is advocating for an integrated rights-based approach to migration to address this disconnect between migration and labour governance.

This chapter analyses the emerging institutional architecture of migration governance from the vantage point of advocacy networks that have taken up the concerns on behalf of, or are run by, the many marginalised migrants (that is, low-wage/low-skill migrant workers employed on temporary contracts), probing into the obstacles to, and opportunities for, shaping the direction of policymaking towards a rights-based approach to migration within this evolving architecture. By introducing a social movement perspective, the elitist project of global migration governance is being re-envisioned and resisted.

\section{Global migration governance: Institutions and rights activism}

In an institutional sense, migration for work is not governed by a formal international regime of the kind that exists for refugees, with the United Nations (UN) High Commissioner for Refugees as the central node. Instead, various UN agencies and international organisations, including international financial institutions, are involved in producing data about the international migration of workers and the translation of such knowledge into policy. It is mainly for this reason that the global architecture of migration governance has been described as fragmented.

Moreover, the International Labour Organization (ILO) as the central standard-setting international organisation (IO) in the realm of labour (migrant and non-migrant) —and, arguably, the only global institution with the potential to combine migration with labour governance-has occupied a marginal position within the emerging migration governance in terms of its ability to assert influence on the direction of the current policy debate (Standing 2008). This may appear somewhat surprising given the fact that migration is linked, directly or indirectly, to the world of work: more than 50 per cent of the 214 million international migrants today are economically active and, together with their families, migrant workers make up over 90 per cent of this total (ILO 2013: 3). However, the inability of the ILO to push itself to the centre of the 
migration governance debate and take a leading role has to do with the general onslaught on workers' rights that has come with the spreading of neoliberalism alongside enhanced global interconnections of economies and production systems.

Global migration governance has, in fact, come about at a specific, historic moment in time when labour in general (that is, migrant and non-migrant) has been subjected to the downgrading of standards through the loss of traditional union rights, which is attributed to the spread of neoliberalism (Standing 2011; Schierup and Castles 2011) and economic globalisation characterised by the 'race to the bottom' in the search for cheaper labour. This trend is reflected in the weakened position of the ILO, the key player in the upholding of migrants' rights in their role as workers (Standing 2008). The organisation's historical success in promoting labour standards can be attributed in part to its tripartite structure, ${ }^{2}$ which has allowed for significant input into the standardsetting process from two specific non-state actors: employers and trade unions.

However, these successes are under pressure from within and from without. Pressure from within includes the lack of inclusion of organisations beyond the traditional employer-employee nexus that has historically emerged from the specific experience of European labourism, which has led to the exclusion of other non-union labour organisations (migrant and non-migrant) (Standing 2008). There are also new stateowned processes of deliberation ${ }^{3}$ that occur outside the UN framework and which pose direct competition to standard-setting organisations like the ILO. In the migration field, the main competitor for the ILO is the International Organization for Migration (IOM), whose mandate is not based on the United Nations' human rights framework. It is an intergovernmental organisation whose work is project-based and, thus, also funding-based (Geiger 2010). In terms of process and participation, global dialogue on migration has become subject to extra-UN processes, such as the annual Global Forum on Migration and Development (GFMD), which is state-led and occurs behind closed doors (apart from

2 This structure refers to three parties that make up its constituency: worker organisations (trade unions), employer associations and governments.

3 In this context, the notion of 'forum shopping' has been used to describe states' choices of suitable sites to advance their interests. We would instead refer to this phenomenon as 'forum shifting' to reflect the perspective of political activist organisations such as trade unions and migrant rights groups for whom this choice given to states means fewer opportunities for participation and less access. 
short 'interspace' sessions with selected members from civil society), thus escaping scrutiny by and input from civil society organisations (such as trade unions and other labour rights organisations). These developments have led critics to argue that without paying greater attention to migrant workers' rights, the benefits of migration are skewed in favour of employers and the ever expanding private recruitment industry ${ }^{4}$ that operates across borders, to the expense of migrants' own benefits (Wickramasekara 2009; Piper 2008). Only a rights-based approach can ameliorate this situation.

The institutional fragmentation of migration governance and the marginal role of the ILO as the most democratic global organisation in procedural terms therein, however, pose serious challenges for the ability of migrant rights advocacy organisations to represent the concerns of their constituencies. To overcome the challenges of institutional barriers, on the one hand, and institutional fragmentation, on the other, migrant rights activists have stepped up their mobilising efforts at the global level, building on pockets of existing national and regional activism. This is well expressed in the following quotation:

Our biggest asset is the existence of global social movements. Our task is to think and work together so that we move beyond advocacy for policy changes, and towards a strong process of inter-movement building so that we can occupy the relevant spaces and challenge the global paradigm. (WSFM 2012: 42)

By embarking on broader social movement building, migrant rights activists have come to address not only the consequences but also the major causes of international migration. The key concept in the development of a comprehensive approach to migrants' rights thereby is 'decent work' applied in a transnational context- that is, to the 'here and there'. This was taken up in the Final Declaration of the World Social Forum on Migration that was held in Manila in 2012; the right not to emigrate should be in place in the countries of origin. This implies creating the necessary conditions that transform migration into a choice rather than a necessity (Clause 31 ).

4 The key issue with the private recruitment industry is the charging of excessive fees to migrants (rather than employers), often in the country of origin and destination countries, which is deemed illegal according to ILO Convention 181. 
The concept of decent work has gained prominence because most forms of international migration have employment-related aspects attached, as cross-border movement of people is largely a response to a lack of economic opportunities 'at home', often accompanied by conditions of insufficient or non-existent social safety nets provided by states (Hujo and Piper 2010). Migrants tend to find themselves in a state of precariousness on the basis of labouring in low-wage sectors, often in an undocumented or contract-tied manner (ILO 2013), and, then, again, post-migration when returning home to often still hopeless situations that often drive migrants into remigration (Spitzer and Piper 2014).

\section{Bringing labour back in}

The management of migration literature and concomitant policy prescriptions are not the only things that have left out concerns for labour relations and working conditions. The call for 'bringing labour back' into academic discourse and conceptualisations of global governance as well as into policy has reappeared from various corners and epistemic circles, voiced most strongly by labour relationists, sociologists and labour geographers (Herod 1995; Munck 2000; Bronfenbrenner 2007 Evans 2010). Calls to study labour have also appeared in the context of global production network analysis - an area of scholarly inquiry marked by an 'inadequate incorporation of labour' (Stringer et al. 2013: 3).

By studying 'networks of labour' beyond macro-structuralist perspectives, such scholars have shifted attention to political agency. Increasing calls to 'bring labour back in' (Cumbers et al.2008) are mainly driven by the imbalance among overtly structural analyses that have shifted worker agency to the back stage (Herod 1995). International relations literature on global governance, in contrast, has neglected labour and, as a result, has not concerned itself with the role of the ILO and trade unions in the study of international organisations and politics. This stands at odds with the fact that, historically, the labour movement has constituted one of the most significant drivers of social reform (Gallin 2000) and an important ally in the struggle for social justice in general (Leather 2004) and migrant labour's rights in particular (Ally 2005; Piper 2010).

Injecting the role of collective agency by social and labour movements into the broader literature on globalisation-especially the combined appreciation of the organisational dimension of globalisation (regulation, governance), the direction global policy is taking in certain issue areas 
and the way in which the outcome is reshaping the lives of real people in the global web of places (cf. Coe and Yeung 2001) — paves the way for a 'bottom-up' perspective on global governance (Grugel and Piper 2007).

\section{Resisting global migration governance from the 'bottom up'}

Within the global governance literature, two issues have attracted considerable scholarly attention: 1 ) the issue of democratic deficit and transparency, given the lack of opportunities for direct participation by civil society organisations (Scholte 2011); and 2) the role of IOs and the degree to which they are independent from states, raising the issue of IOs'levels of autonomy (Finnemore 1993).

The latter strand of the literature questions whether IOs are constrained by the sovereign (and financial) power of states or whether they are autonomous organisations capable of setting up independent programs, and even influencing public policy (Loescher 2001; Finnemore 1993; Charnock 2006; on migration, see Geiger 2010). Overall, much of the existing scholarship on IOs has focused on the relationship between IOs and states, with most analyses of global governance tending to centre on the operation of power and changes within the configuration of that power in the context of global institutions. Far less is known about 'bottom-up governance' and the relationships of conflict and resistance that emerge at the interface between vulnerable groups of people (here, migrant workers), global governance institutions and states, especially from the perspective of civil society activists.

In the realm of human rights theorising, of which labour and migrant rights are a subgroup, it is the contradictory role of the state-as oppressor or violator of rights, on the one hand, and the primary agent of justice or deliverer of rights, on the other-that constitutes a paradox (Pogge 2001; Kuper 2005b). This is the main reason social movement scholars argue that the state remains the principal target for political action (Grugel 2004; Tarrow 2006). Yet, there is also increasing recognition of the role and responsibility of transnational actors in global politics (Jönsson and Tallberg 2010), as both violators of human rights (as evident in the increasing prominence of the "human rights and business' debate) and those responsible for realising rights (Kuper 2005a). In this context, the debate on global governance has concentrated 
on the question of whether cooperation within the international system, together with the integration of new private actors, makes it more democratic, legitimate and accountable (Zürn 2005; Erman and Uhlin 2010). This last concern has triggered increased interest in the contribution of civil society organisations (CSOs) to democratising public sector institutions at any level (Scholte 2011).

In the human rights field, it has been shown that global norms are increasingly shaped through interaction between states, international institutions and activist networks, many of which (such as peasants, farmers, female informal sector workers and so on) today emanate from the global South (Rajagopal 2012). The fact that global norms and legal enforcement are increasingly influenced by the everyday resistance of ordinary people, channelled through collective organisations, points to the relevance of social movements and, thus, to a theory of resistance derived from the mobilising of hitherto marginal or non-existent political constituencies (Stammers 2009; see also Charlesworth, Chapter 21, this volume). In this sense, as argued by Rajagopal (2012), it is inadequate to analyse human rights from the exclusive perspective of states (as realists/positivists would do) or from the exclusive perspective of the individual (as liberals would do).

Hence, a conceptualisation of resistance is put forward here that takes transformative mobilisation as its core feature, whereby 'transformative' is used to refer to changing institutional practices pushed from below via activist networks. In this sense, the case of the global migrant rights movement falls into the category of 'overt' resistance (as per the typology developed by Hollander and Einwohner 2004) — that is, a category of resistance that involves visible behaviour easily recognisable by targets and observers and, thus, includes collective acts such as mobilisation by, or into, social movements. However, as social movement literature has predominantly concerned itself with grassroots mobilisation, constructivist international relations scholarship has to be brought in as it highlights the socially constructed nature of international relations (in contrast with pure materialism) and, thus, opens up an avenue for the role of ideas in international advocacy. Unlike classic social movement scholarship, international relations has the benefit of addressing political contention in a cross-border context. This allows for analysis and conceptualisation of transnational social movements. Transnational 
advocacy networks are the primary actors in the pursuit of social justice and human rights vis-a-vis global governance processes and institutions (Keck and Sikkink 1998).

Importantly, international relations and development studies scholarship on global governance have also raised the issue of the democratic deficit inherent in supranational policymaking processes. It is, however, not sufficient to simply highlight the democratic deficit of international organisations in operational and processual terms, but to delve into the actual achievement of transformative justice via institutional change. In an abstract sense, resistance concerns struggles for human freedom and liberation from structural oppression and exploitation (Gills and Gray 2012). In relation to migration governance, this relates to greater freedom of mobility that would render migration a choice, not a necessity (GCIM 2005; UNDP 2009). In concrete terms, transformation of institutions has to come from the bottom up-and, in the context of global governing institutions, from 'global justice networks' (Routledge and Cumbers 2009). Given the fragmented nature of global migration governance, for resistance to have an effective impact it has to address this institutional complexity by engaging in equally complex 'networks of networks'.

\section{Nascent global migrant rights movement}

The recent developments around the tabling and subsequent adoption of ILO Convention No. 189 on Decent Work for Domestic Workers in 2011 constitute an example of the successful strategy of forming 'networks of networks' between migrant rights organisations and trade unions. The adoption of ILO Convention No. 189, which constitutes a political victory, is an instrument that regulates a hitherto unregulated sector in the informal economy whose workforce is primarily female and primarily located in or drawn from the global South, migrant and nonmigrant. Although it was formally adopted by two-thirds of the ILO's 185 member states at its annual congress in 2012 and formally entered into force as of September 2013, the remaining challenge is to boost its ratification record (as of December 2014, there were 16 ratifications).

Importantly, the success of the ILO convention is related to the networks of networks. It was the involvement of unconventional unionists and migrant worker organisations that, in fact, revived the entire ILO process and its usually very routinised and highly technical procedures. Senior 
ILO staff found this new approach very refreshing and stimulating (Personal interviews, conducted in 2011 and 2012). Whether or not opening up channels to domestic and migrant worker organisations constitutes a breakup of the sacrosanct tripartite structure of the ILO by turning this into a consistent feature of the organisation is yet to be seen. But it is a step in the right direction, as pointed out by critics who have argued for the ILO's institutional renewal and inclusion of non-traditional types of workers (Standing 2008), who make up the majority of workers. In this way, the ILO would also become relevant to the situation of workers in the global South (Sen 2000).

At the global level, migrant rights organisations and their regional networks formed the Peoples' Global Action on Migration, Development and Human Rights (PGA) in response to the state-led process and closeddoor deliberations of the GFMD and the broad-based composition of its Civil Society Days. The PGA was established at the first global meeting on international migration and development held at UN level, the UN High Level Dialogue on Migration and Development, in 2006. It comprises regional and national migrant rights networks, supported by global and a few national trade unions. ${ }^{5}$ At the PGA in Mexico City in 2010, for instance, there were nearly 800 delegates representing migrant associations, trade unions, human rights and women's groups, faith-based and anti-poverty organisations as well as academics.

The PGA brings together groups from around the world and provides essential space for lobbying and pressuring governments and international bodies to look at migration — and development—from a human rights perspective and to make governments accountable to their international human rights and development commitments. Furthermore, PGA paves the way for capacity building and establishment or widening of networks.

Born of the PGA process is the Global Coalition of Migration (GCM), the first truly global initiative aimed at the promotion of migrants' rights. It constitutes a formal alliance of global unions, regional and national networks of membership-based migrant rights organisations from Europe, Asia, Africa, Latin America and North America as well as two academic research networks. It uses the network form of operation to share information and resources and to develop common

5 Those are: Building and Woodworkers International (BWI), Irish Congress of Trade Unions (ICTU), Public Services International (PSI), the Canadian Trade Union Council and American Federation of Labor and Congress of Industrial Organizations (AFL-CIO). 
strategies. One such strategy is to broaden and reach out to other social movements - such as Via Campensina, the peasant movement that is now part of the GCM-based on the personal experience of displacement of many peasants and the subsequent migration of their wives or other female family members to work overseas as domestic workers.

\section{Concluding remarks}

To overcome the challenges posed by multiple institutional deficiencies and barriers to participation in decision-making processes at the global level, migrant rights activists have begun to step up their mobilising efforts around the globe. Building on grassroots migrant activism, transnational advocacy networks have been formed and broader social movement building, including transnational campaigns for labour standards and labour rights, embarked on. In so doing, migrant rights advocates have developed a comprehensive approach to migrant rights that addresses not only the consequences but also the major causes of international migration. Such initiatives are challenging elitist ('top-down') projects of global governance by articulating alternative visions based on international human and labour rights principles ('bottom-up governance').

It is through the CSO-led processes that a radical rethinking of migration and the socioeconomic development models that surround its governance is being pursued. These CSO gatherings are used to deepen the analysis of the migration-development nexus and to sharpen their counterdiscourse of what they view as a systematised labour exportimport program practised on a global scale. In their interpretation, such practice amounts to forced migration and, thus, is replete with human and labour rights' violations.

The key messages that have emanated from these 'networks of networks' and cross-sectoral alliances are: guarantee the right to free movement, on the one hand, and, on the other, the creation of employment/livelihood opportunities for people 'at home'-that is, the right not to have to migrate in the first place. The activists are politically savvy enough to realise that the 'right not to have to migrate' can be misinterpreted and abused by anti-migrant constituencies in mostly migrant-receiving countries. Instead, they resort to the demand for decent work 'here' and 
'there', thus making use of the ILO's inclusive framework-inclusive of migrants and non-migrants as well as of the situation of sending and receiving communities.

In sum, the unified message that has come out of the CSO-led initiatives in response to the migration-development nexus and 'management of migration' discourse promoted by global governing bodies is that development goes beyond economics and involves comprehensive human, or people-centred, development. Instead of the current migration-development paradigm that views migrants as agents of development in the neoliberal sense of 'self-help' in an era of increasing privatisation of public goods, the demand is for a refocusing on the migration-employment nexus, which combines migration and labour governance - and, therefore, puts the ILO at centre-stage in the global governance of migration. In this way, an integrated rights-based approach to migration is conceptually developed and politically fought for that combines migration and labour governance from a holistic (that is, transnational) perspective.

\section{Further reading}

Basok, T and Piper, N 2012. 'Management versus rights: Women's migration and global governance in Latin America and the Caribbean', Feminist Economics 18(2): 1-26. doi.org/10.1080/13545 701.2012.690525.

Kneebone, S 2010. 'The governance of labor migration in Southeast Asia', Global Governance 16(3): 383-96.

Schierup, CU, Alund, A and Likic-Brboric, B 2015. 'Migration, precarization and the democratic deficit in global governance', International Migration 53(5): 50-63. doi.org/10.1111/imig.12171.

\section{References}

Ally, S 2005. 'Caring about care workers: Organizing in the female shadow of globalization', Labour, Capital and Society 38(1-2): 185-207.

Betts, A (ed.) 2011. Global Migration Governance. Oxford: University of Oxford Press. 
Bronfenbrenner, K (ed.) 2007. Global Unions: Challenging Transnational Capital through Cross-Border Campaigns. Ithaca, NY: Cornell University Press.

Charnock, G 2006. 'Improving the mechanisms of global governance? The ideational impact of the World Bank on the national reform agenda in Mexico', New Political Economy 11(1): 73-98. doi. org/10.1080/13563460500494909.

Chi, X 2008. 'Challenging managed temporary labor migration as a model for rights and development for labor-sending countries', New York University Journal of International Law and Politics 40(2): 497-540.

Coe, N and Yeung, H 2001. 'Geographical perspectives on mapping globalisation', Journal of Economic Geography 1(4): 367-456. doi. org/10.1093/jeg/1.4.367.

Cumbers, A, Nativel, C and Routledge, P 2008. 'Labour agency and union positionalities in global production networks', Journal of Economic Geography 8(3): 369-87. doi.org/10.1093/jeg/lbn008.

Erman, E and Uhlin, A (eds) 2010. Legitimacy beyond the State? Re-examining the Democratic Credentials of Transnational Actors. Basingstoke, UK: Palgrave Macmillan.

Evans, PB 2010. 'Is it labor's turn to globalize? Twenty-first century opportunities and strategic responses', Global Labour Journal 1(3): 352-79. doi.org/10.15173/glj.v1i3.1082.

Falk, R 1995. On Human Governance: Toward a New Global Politics. University Park, PA: Pennsylvania State University Press.

Finnemore, M 1993. 'International organizations as teachers of norms: The United Nations Educational Scientific and Cultural Organization and science policy', International Organization 47(4): 565-97. doi. org/10.1017/S0020818300028101.

Gallin, D 2000. Trade unions and NGOs: A necessary partnership for social development-Programme on Civil Society and Social Movements, Civil Society and Social Movements Programme Paper No. 1, United Nations Research Institute for Social Development, Geneva. 
Geiger, M 2010. 'Mobility, development, protection, EU-integration! IOM's national migration strategy for Albania', in M Geiger and A Pécoud (eds), The Politics of International Migration Management. Basingstoke, UK: Palgrave Macmillan, pp. 141-59. doi. org/10.1057/9780230294882_7.

Gills, BK and Gray, K 2012. 'People power in the era of global crisis: Rebellion, resistance and liberation', Third World Quarterly 33(2): 205-24. doi.org/10.1080/01436597.2012.664897.

Global Commission on International Migration (GCIM) 2005. Migration in an Interconnected World: New Directions for Action. Geneva: GCIM.

Grugel, J 2004. 'State power and transnational activism', in N Piper and A Uhlin (eds), Transnational Activism in Asia: Problems of Power and Democracy. London: Routledge, pp. 21-39.

Grugel, J and Piper, N 2007. Critical Perspectives on Global Governance: Rights and Regulation in Governing Regimes. London: Routledge.

Habermann, F 2011. 'Transnationale soziale Bewegungen [Transnational social movements]', in A Ilker, A Kraler and A Ziai (eds), Politik und Peripherie [Politics and Periphery]. Vienna: Mandelbaum Verlag, pp. 243-56.

Herod, A 1995. 'The practice of international labor solidarity and the geography of the global economy', Economic Geography 71(4): 341-63. doi.org/10.2307/144422.

Hollander, JA and Einwohner, RL 2004. 'Conceptualizing resistance', Sociological Forum 19(4): 533-54. doi.org/10.1007/s11206-0040694-5.

Hujo, L and Piper, N (eds) 2010. South-South Migration: Implications for Social Policy and Development. Basingstoke, UK: Palgrave.

International Labour Organization (ILO) 2013. Labour migration and development: ILO moving forward, Background Paper for discussion at the ILO Tripartite Technical Meeting on Labour Migration (Geneva, 4-8 November 2013), ILO, Geneva. Available at: ilo. org/wcmsp5/groups/public/---ed_protect/---protrav/---migrant/ documents/meetingdocument/wcms_222548.pdf. 
Jönsson, C and Tallberg, J (eds) 2010. Transnational Actors in Global Governance: Patterns, Explanations, and Implications. Basingstoke, UK: Palgrave Macmillan.

Keck, M and Sikkink K 1998. Activists beyond Borders: Advocacy Networks in International Politics. Ithaca, NY: Cornell University Press.

Kennedy, P, Messner, D and Nuscheler, F (eds) 2002. Global Trends and Global Governance. London: Pluto Press.

Koser, K 2010. 'Introduction: International migration and global governance', Global Governance 16(3): 301-15. doi. org/10.1057/9780230281509_1.

Kuper, A 2005a. 'Global poverty relief: More than charity', in A Kuper (ed.), Global Responsibilities: Who Must Deliver on Human Rights? London: Routledge, pp. 155-70.

Kuper, A (ed.) 2005b. Global Responsibilities: Who Must Deliver on Human Rights? London: Routledge.

Leather, A 2004. 'Guest editorial: Trade union and NGO relations in development and social justice', Development in Practice 14(1-2): 13-19.

Loescher, G 2001. 'The UNHCR and world politics: State interests vs. institutional autonomy', International Migration Review 35(1): 33-56. doi.org/10.1111/j.1747-7379.2001.tb00003.x.

Munck, R 2000. 'Labour in the global: Challenges and prospects', in R Cohen and SM Rai (eds), Global Social Movements. London: The Athlone Press, pp. 83-100.

Piper, N 2008. "The "migration-development nexus" revisited from a rights perspective', Journal of Human Rights 7(3): 282-98. doi. org/10.1080/14754830802285964.

Piper, N 2010. 'Temporary economic migration and rights activism: An organisational perspective', Ethnic and Racial Studies 1(1): 1-33. doi.org/10.1080/01419870903023884.

Pogge, T 2001. World Poverty and Human Rights. Cambridge: Polity Press. 
Rajagopal, B 2012. 'International law and social movements: Challenges to theorizing resistance', Columbia Journal of Transnational Law 41: 397-432.

Rittberger, V 2001. Global Governance and the United Nations System. Tokyo: United Nations University Press.

Routledge, P and Cumbers, A 2009. Global Justice Networks: Geographies of Transnational Solidarity. Manchester: Manchester University Press. doi.org/10.7228/manchest er/9780719076855.001.0001.

Schierup, CU and Castles, S 2011. 'Migration, minorities and welfare states', in N Phillips (ed.), Migration in the Global Political Economy. London: Lynne Rienner Publishers, pp. 15-40.

Scholte,JA 2011. Building Global Democracy? Civil Society and Accountable Global Governance. Cambridge: Cambridge University Press. doi. org/10.1017/CBO9780511921476.

Sen, A 2000. 'Work and rights', International Labour Review 139(2): 119-28. doi.org/10.1111/j.1564-913X.2000.tb00406.x.

Spitzer, D and Piper, N 2014. 'Retrenched and returned: Filipino migrant workers during times of crisis', Sociology 48(5): 1007-23. doi. org/10.1177/0038038514540579.

Stammers, N 2009. Human Rights and Social Movements. London: Pluto Press.

Standing, G 2008. 'The ILO: An agency for globalization?', Development and Change 39(3): 355-84. doi.org/10.1111/j.14677660.2008.00484.x.

Standing, G 2011. The Precariat: The Nerw Dangerous Class. London: Bloomsbury Academic.

Stringer, C, Simmons, G, Coulston, D and Whittaker, DH 2013. 'Not in New Zealand's water, surely? Linking labour issues to GPNs', Journal of Economic Geography 10(3): 1-20.

Tarrow, S 2006. 'Confessions of a recovering structuralist', European Political Science 5: 7-20. doi.org/10.1057/palgrave.eps.2210064. 
United Nations Development Programme (UNDP) 2009. Human Development Report 2009: Overcoming Barriers-Human Mobility and Development. Basingstoke, UK: Palgrave Macmillan.

Wickramasekara, P 2009. 'Development, mobility and human rights: Rhetoric and reality', Refugee Survey Quarterly 28(4): 165-200. doi. org/10.1093/rsq/hdq016.

World Social Forum on Migration (WSFM) 2012. Mobility, rights, global models: Looking for alternatives, Declaration of the 5th World Social Forum on Migration, Manila, 26-30 November.

Zürn, M 2005. 'Global governance and legitimacy problems', in D Held and M Koenig-Achibugi (eds), Global Governance and Public Accountability. London: Blackwell, pp. 136-63. 
This text is taken from Regulatory Theory: Foundations and applications, edited by Peter Drahos, published 2017 by ANU Press, The Australian National University, Canberra, Australia. 